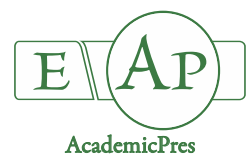

\title{
Assessment of Genetic Diversity of an Endangered Species Fraxinus hupebensis Based on ISSR Markers
}

\author{
Peng-Li ZHENG ${ }^{1}$, Jian-Ru CHENG ${ }^{1}$, Long-Qing CHEN², \\ Ming-Qin $\mathrm{ZHOU}^{1 *}$ \\ ${ }^{1}$ Yangtze University, College of Horticulture and Gardening, Jingzhou 434025, Hubei, \\ China; 1271379364@qq.com; 553894234@qq.com; 500548@yangtzeu.edu.cn ("corresponding author) \\ ${ }^{2}$ Southwest Forestry University, College of Landscape Architecture and Horticulture Sciences, Kunming 650224, Yunnan, \\ China; clqhzau@126.com
}

\begin{abstract}
Investigation on the level and pattern of genetic diversity of 10 natural populations of the endangered species Fraxinus hupehensis using inter-simple sequence repeat (ISSR) markers was crucial for understanding the structure of the population and assessing the best genetic protection strategies. A total of 180 polymorphic bands with the polymorphic rate of $100.00 \%$ were amplified by 14 primers. The genetic diversity at population level (Percentage of polymorphic loci, PPL=64.06; Nei's gene diversity index, $h=0.1519$; Shannon's information index, $I=0.2434)$ was lower than that at species level $(\mathrm{PPL}=100.00 \%$, $h=0.1833, I=0.3041)$. Analysis of molecular variance (AMOVA) demonstrated the low level of the genetic variation occurred between the populations (16.05\%). This also can be corroborated by the gene flow $(\mathrm{Nm} 2.424)$ and the coefficient of gene differentiation $(G s t=0.1710)$ among populations. Cluster analysis based on the unweighted pair group method with arithmetic averages (UPGMA) revealed four groups for 10 populations according to Nei's genetic identity and seven categories for the 196 individuals according to SM values. Furthermore, the endangered mechanism and genetic structure of $F$. hupehensis were discussed, and appropriate targeted protection measures were proposed based on these findings.
\end{abstract}

Keywords: Fraxinus hupehensis; genetic diversity; genetic structure; ISSR; natural populations

\section{Introduction}

Fraxinus hupehensis Chiú. Shang et $\mathrm{Su}$, a deciduous tree of the family Oleaceae, was officially designated as the secondary rare and endangered protected plants in China in 1990 (Peng, 1990). Because of the advantages of oval canopy, beautiful branches and leaves, bright green color, winter flowering, few diseases and insect pests, strong adaptability, a long life span and so on, $F$. hupehensis has been not only widely used as a beautiful landscape tree species, but also excellent bonsai and root carving materials, known as the 'living fossil', 'king of bonsai'.

The wild $F$. hupehensis germplasm resources exist only in the Dahong Mountain and the neighboring areas near the junction of Zhongxiang city and Jingshan County in Hubei province, with narrow distribution range, small population scale and being scarce in quantity (Ming and Liao, 1998). Especially in recent years, the wild resources have been overexploited and destroyed seriously, in view of its high application value of making bonsai or tree stumps.
Conservation of endangered plants is an important component of biodiversity conservation. For successful conservation and breeding of a endangered species, it is important to evaluate its genetic diversity. To data a majority of studies on $F$. hupehensis have focused on the propagation and cultivation techniques, such as seed propagation (Ye et al., 1999), cuttage propagation (Wang et al., 2001; An et al., 2013) and tissue culture (Wang et al., 1999; Zhang et al., 2014). Few studies have been reported on the genetic structure and genetic diversity, although such research is essential to detect the genetic variation and differentiation within and among populations and to establish an appropriate protection policy for $F$. hupehensis.

Studies on the genetic diversity, the choice of appropriate genetic markers assumes a great significance (Monfared et al., 2018). Morphological and biochemical characters have been used traditionally to characterize levels and patterns of diversity, but these likely to be affected by the environment and cultivation conditions (Liu et al., 2013; Cao et al., 2019). ISSR is a technique for detecting 
nuclear genomic DNA polymorphism developed by zietkiewicz et al. (1994), and it's widely seen as an effective tool in the fields of plant genetic diversity (Pomper et al., 2003), QTL genes (Zou et al., 2018), genetic map construction (Nishijima et al., 2018), and variety identification (Liu et al., 2007). In this study, on the premise of conducting a comprehensive survey on the distribution of wild germplasm resources and habitat conditions of $F$. bupehensis, the genetic diversity of $F$. hupehensis populations were analyzed by using ISSR marker method. The aims were: (1) to evaluate the genetic diversity at population level and species level; (2) to assess the genetic structure among and within populations, and (3) to propose targeted protection measures for $F$. hupebensis.

\section{Materials and Methods}

Plant material

The materials used in this research were collected from 196 individuals in the 10 natural populations of Kedian,
Jimingsi, Dakoulin, Huzhuashan, Sunqiao, Kongshandong, Yanmenkou, Guanyinyan, Yongxin and Yangii (designated as KD, JMS, DKL, HZS, SQ, KSD, YMK, GYY, YX, YJ, respectively) in Jingshan and Zhongxiang of Hubei province, and the sample size was 16, 36, 6, 31, 19, 17, 21, $21,12,25$, respectively (Table 1 , Fig. 1 ). The populations are isolated, independent and disconnected from each other. In each population, approximately $5 \mathrm{~g}$ of fresh leaves per plant were randomly collected from adult trees at least 10 meters apart; therefore, the number of samples reflected the size of the corresponding population. After being dried in silica gel for transportation, the leaves samples have been frozen in $-80{ }^{\circ} \mathrm{C}$ in freezer in the Key Laboratory of Horticultural Plant Biology of China for DNA extraction.

DNA extraction and ISSR reaction system establishment

The modified cetyl trimethyl ammonium bromide (CTAB) method described by Ye et al. (2017) was used to extract $F$. hupehensis genomic DNA. The quality of $F$. bupehensis genomic DNA was measured by electrophoresis and Nanodrop 2000C nucleic acid protein analyzer.

Table 1. The detailed information about 10 natural populations

\begin{tabular}{cccc}
\hline Number & Population & Location & Sample size \\
\hline 1 & KD & Kedian & 16 \\
2 & JMS & Jiming S & 36 \\
3 & DKL & Dakoulin (Zhongxiang city) & 31 \\
4 & HZS & Huzhushan & 19 \\
6 & SQ & Sunqiao & 17 \\
7 & KSD & Kongshandong & 21 \\
9 & YMK & Yanmenkou & 21 \\
10 & GYY & Guanyinyan & 12 \\
\hline
\end{tabular}

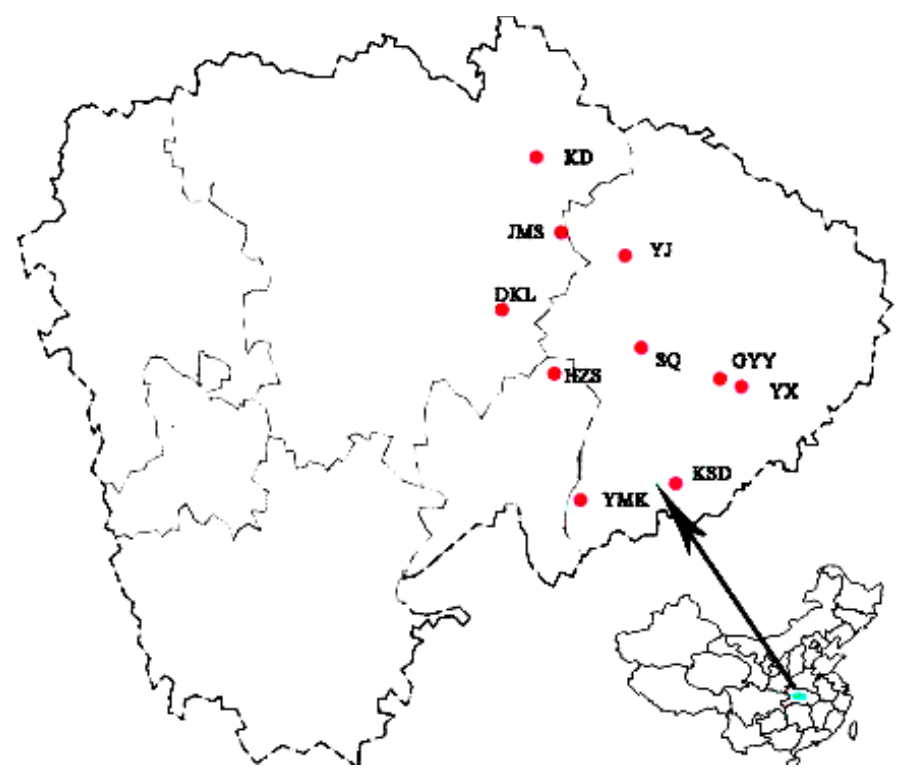

Fig. 1. Geographical distribution of 10 populations in Jingmen city as has been described in Table 1 
1310

ISSR-PCR analysis were performed in $15 \mu \mathrm{L}$ final reaction volumes, containing $7.5 \mu \mathrm{L} 2 \times \mathrm{T}$ aq Plus Master Mix, $1.05 \mu \mathrm{L}$ ISSR primer, $2 \mu \mathrm{L}$ template DNA (20ng/L), $4.45 \mu \mathrm{L}$ RNase-Free Water. Reactions were carried out in a PTC-100 thermal cycler (MJ Research Thermocycler) according to the following amplification profile: predenaturing at $94^{\circ} \mathrm{C}$ for 5 minutes, followed by 38 cycles of denaturation at $94^{\circ} \mathrm{C}$ for 30 seconds, and annealing at the optimum annealing for 90 seconds and extension at $72{ }^{\circ} \mathrm{C}$ for 90 seconds, and a final extension of 7 minutes at $72^{\circ} \mathrm{C}$. The $5 \mu \mathrm{L}$ amplification products were electrophoresed in $1 \times$ TAE buffer with $1.5 \%$ agarose gel containing GelRed nucleic acid dye at $120 \mathrm{~V}$ for about $30 \mathrm{~min}$, then photographed under a UV light with a gel system .

A total of 52 ISSR primers sequences concerned in this study were provided by the Biotechnology Laboratory, University of British Columbia (UBC), synthesized by Beijing Tianyi Huiyuan Biological Company, and preliminarily screened with six DNA samples which were randomly selected from six different populations.

\section{Data analysis}

The ISSR bands were counted using the binary scoring system and the amplified fragments at an amplicon level were assessed as present (1) or absent (0). The polymorphic information content (PIC) was used to describe the informativeness of the primer, which was calculated by the formula: $\mathrm{PIC}=2 f_{i}\left(1-f_{i}\right)$, where $f_{i}$ is the percentage of the ith amplified and present band (Anderson et al., 1993). The Marker index (MI) was the product of PIC and the total number of polymorphic bands amplified by per primer.

Using the software POPGENE 1.31 (Yeh et al., 1999), the percentage of polymorphic loci (PPL), the observed number of alleles $\left(N_{a}\right)$, the effective number of alleles $\left(N_{e}\right)$ (Kimura and Crow, 1964), Nei's gene diversity $(b)$ (Nei, 1973), Shannon's information index (I) (Lewontin, 1972), the total gene diversity $(H \mathrm{t})$, and the gene diversity within population $\left(H_{s}\right)$ were used to examine genetic diversity within and among populations. The coefficient of gene differentiation $(G \mathrm{st})$, gene flow $\left(\mathrm{N}_{\mathrm{m}}\right)$ (McDermott and McDonald, 1993), genetic distance, Nei's genetic identity
(Marques et al., 2018) were used to examine the genetic relationship and the degree of genetic differentiation among populations. Using NTSYS-pc2.10, the similarity coefficient matrix was obtained based on Simple Matching (SM) similarity coefficient. According to the unweighted pair group method with the arithmetic averaging algorithm (UPGMA), the cluster analysis among 196 individuals from the 10 populations was conducted based on SM value. The genetic variation among and within the 10 natural populations was calculated with the program analysis of molecular variance (AMOVA) 1.55 (Excoffier $e t$ al., 1992).

\section{Results}

\section{Primer selection and amplification}

The 14 primers were selected from the initial 52 primers for PCR amplification of 196 F. hupehensis samples from 10 populations. A total of 180 bands were amplified with a size from 250 to $2700 \mathrm{bp}$, the polymorphic band percentage of which was $100 \%$. The PIC and MI values of the primers were in the range of $0.29-0.48$ and $2.51-9.02$, respectively. The number of polymorphic bands generated by each primer ranged from 7 (UBC815, UBC822) to 26 (UBC873), with an average of 12.86 bands (Table 2).

\section{Genetic diversity}

When calculated among the 10 natural populations, the lowest PPL value of the population was $40.56 \%$ (DKL), and the highest value was $85.00 \%$ (HZS), with an average of 64.06\%. $N_{\mathrm{a}}$ ranged from $1.4056(\mathrm{DKL})$ to 1.8500 (HZS), with an average of 1.6406. The highest values of $N_{e}, h$, and $l$ were obtained for the DKL population $(1.1894,0.1180$, $0.1845)$, while the lowest values were found in the YMK population $(1.2765,0.1775,0.2825)$. At the species level, the values of PPL, $N_{\mathrm{a}}, N_{o} h, I, H \mathrm{t}, H_{\mathrm{s}}$ were $100 \%, 2.0000$, $1.2769,0.1833,0.3041,0.1832$ and 0.1519 , respectively (Table 3). PPL, $h, N_{a}, N_{e}$ and $I$ reflected the richness of genetic diversity of population together, which showed the order of genetic diversity from large to small in this research was $\mathrm{HZS}>\mathrm{JMS}>\mathrm{YMK}>\mathrm{GYY}>\mathrm{KD}>\mathrm{SQ}>\mathrm{KSD}>\mathrm{YJ}$ $>\mathrm{YX}>\mathrm{DKL}$ (Fig. 2).

Table 2. The amplified information of 14 selected ISSR primers for 196 samples from 10 natural populations

\begin{tabular}{|c|c|c|c|c|c|c|c|}
\hline Primer & Sequence & $\begin{array}{c}\text { Annealing } \\
\text { temperature }\left({ }^{\circ} \mathrm{C}\right)\end{array}$ & $\begin{array}{l}\text { Number of } \\
\text { total bands }\end{array}$ & $\begin{array}{c}\text { Number of } \\
\text { polymorphic bands }\end{array}$ & $\begin{array}{c}\text { Percentage of polymorphic } \\
\text { bands }(\%)\end{array}$ & PIC & MI \\
\hline UBC807 & $(\mathrm{AG})_{8} \mathrm{~T}$ & 50 & 8 & 8 & 100 & 0.46 & 3.70 \\
\hline UBC815 & $(\mathrm{CT})_{8} \mathrm{G}$ & 52 & 7 & 7 & 100 & 0.36 & 2.51 \\
\hline UBC822 & $(\mathrm{TC}) 8 \mathrm{~A}$ & 50 & 7 & 7 & 100 & 0.48 & 3.36 \\
\hline UBC823 & $(\mathrm{TC})_{8} \mathrm{C}$ & 51 & 11 & 11 & 100 & 0.41 & 4.50 \\
\hline UBC824 & $(\mathrm{TC})_{8} \mathrm{G}$ & 51 & 8 & 8 & 100 & 0.33 & 2.64 \\
\hline UBC840 & $(\mathrm{GA})_{8} \mathrm{YT}$ & 52 & 12 & 12 & 100 & 0.29 & 3.52 \\
\hline UBC841 & $(\mathrm{GA}) 8 \mathrm{YC}$ & 52.3 & 12 & 12 & 100 & 0.41 & 4.90 \\
\hline UBC843 & $(\mathrm{CT})_{8} \mathrm{RA}$ & 46.3 & 10 & 10 & 100 & 0.40 & 4.03 \\
\hline UBC844 & $(\mathrm{CT})_{8} \mathrm{RC}$ & 57 & 13 & 13 & 100 & 0.38 & 4.90 \\
\hline UBC866 & (CTC) 8 & 59.9 & 17 & 17 & 100 & 0.35 & 5.91 \\
\hline UBC873 & $(\mathrm{GACA})_{4}$ & 50.9 & 26 & 26 & 100 & 0.35 & 9.02 \\
\hline UBC874 & $(\mathrm{CCCT})_{4}$ & 52.1 & 13 & 13 & 100 & 0.44 & 5.75 \\
\hline UBC876 & $(\mathrm{GATA})_{2}(\mathrm{GACA})_{2}$ & 47.5 & 20 & 20 & 100 & 0.32 & 6.48 \\
\hline UBC878 & $(\text { GGAT })_{4}$ & 48 & 16 & 16 & 100 & 0.41 & 6.48 \\
\hline Average & -.- & -.. & 12.85 & 12.85 & 100 & 0.385 & 4.84 \\
\hline
\end{tabular}


Table 3. The analysis of genetic diversity among the 10 natural populations of Fraxinus hupehensis

\begin{tabular}{cccccccc}
\hline Population & Number & PPL & PPL $(\%)$ & $N a$ & $N e$ & $b$ & $I$ \\
\hline KD & 16 & 118 & 65.56 & $1.6556 \pm 0.4765$ & $1.2611 \pm 0.3318$ & $0.1616 \pm 0.1763$ & $0.2562 \pm 0.2496$ \\
JMS & 36 & 142 & 78.89 & $1.7889 \pm 0.4092$ & $1.2480 \pm 0.2964$ & $0.1613 \pm 0.1609$ & $0.2640 \pm 0.2271$ \\
DKL & 6 & 73 & 40.56 & $1.4056 \pm 0.4924$ & $1.1894 \pm 0.3005$ & $0.1180 \pm 0.1669$ & $0.1845 \pm 0.2458$ \\
HZS & 31 & 153 & 85.00 & $1.8500 \pm 0.3581$ & $1.2630 \pm 0.3032$ & $0.1702 \pm 0.1620$ & $0.2787 \pm 0.2246$ \\
SQ & 19 & 112 & 62.22 & $1.6222 \pm 0.4862$ & $1.2273 \pm 0.3011$ & $0.1457 \pm 0.1647$ & $0.2350 \pm 0.2376$ \\
KSD & 17 & 103 & 57.22 & $1.5722 \pm 0.4961$ & $1.2563 \pm 0.3384$ & $0.1556 \pm 0.1831$ & $0.2418 \pm 0.2618$ \\
YMK & 21 & 126 & 70.00 & $1.7000 \pm 0.4595$ & $1.2765 \pm 0.3027$ & $0.1775 \pm 0.1685$ & $0.2825 \pm 0.2424$ \\
GYY & 21 & 124 & 68.89 & $1.6889 \pm 0.4642$ & $1.2386 \pm 0.2893$ & $0.1558 \pm 0.1610$ & $0.2534 \pm 0.2311$ \\
YX & 12 & 94 & 52.22 & $1.5222 \pm 0.5009$ & $1.2085 \pm 0.2854$ & $0.1344 \pm 0.1644$ & $0.2141 \pm 0.2425$ \\
YJ & 25 & 108 & 60.00 & $1.6000 \pm 0.4913$ & $1.2169 \pm 0.2949$ & $0.1390 \pm 0.1650$ & $0.2234 \pm 0.2398$ \\
Average & 19.6 & 115.3 & 64.06 & 1.6406 & 1.2386 & 0.1519 & 0.2434 \\
Spies level & 196 & 180 & 100 & $2.0000 \pm 0.0000$ & $1.2769 \pm 0.2897$ & $0.1833 \pm 0.1517$ & $0.3041 \pm 0.2050$ \\
\hline
\end{tabular}

Note: PPL: Percentage of polymorphic loci; $b$ : Nei's gene diversity index; I: Shannon's information index; Ne: effective number of alleles; Na: the observed number of alleles.

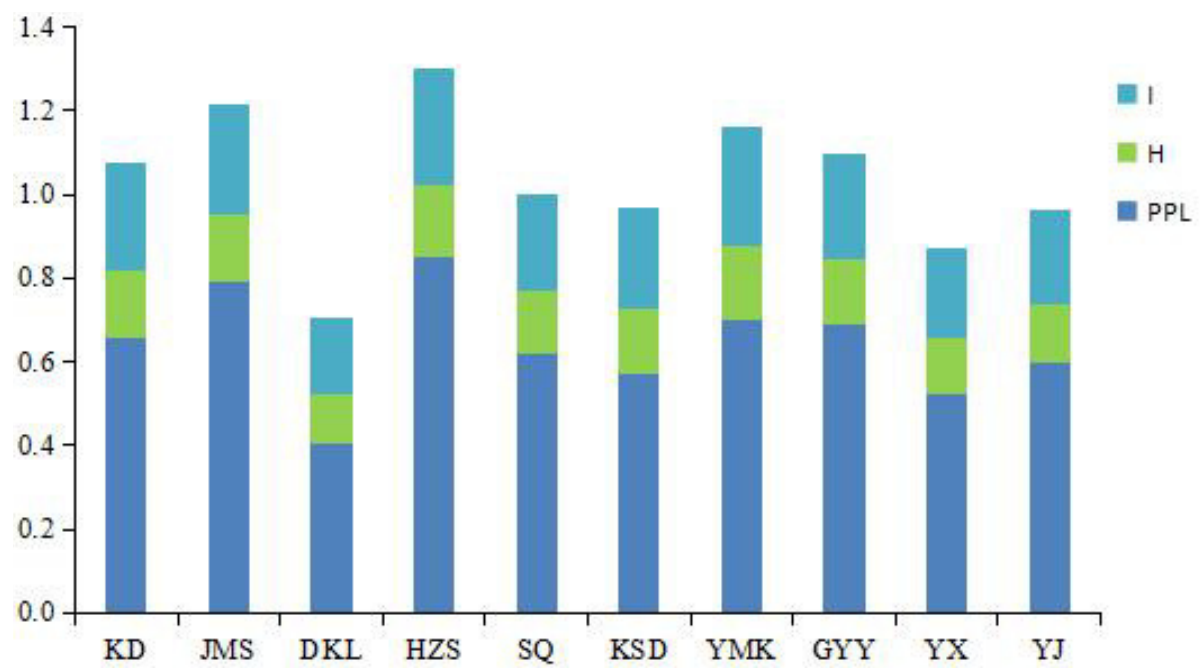

Fig. 2. Comparative analysis of genetic diversity indices of 10 natural populations. PPL: Percentage of polymorphic loci; $h$ : Nei's gene diversity index; I: Shannon's information index

\section{Genetic structure}

The parameter of variations within and among populations was demonstrated by AMOVA, which showed occurrence of $16.05 \%$ of genetic variations among the populations. It implies that existing $83.95 \%$ variations within the population (Table 4). The gene flow observed among populations was quite considerable (2.4243), and this also confirmed by the mean coefficient of gene differentiation $(G$ st $=0.1710)$, indicated that the gene communication among populations was relatively rich.

\section{Genetic relationship}

Among the 10 natural populations, the shortest genetic distance (0.0173) and the highest genetic identity (0.9829) were obtained for population of YX and YJ, and the greatest genetic distance (0.0839) and the lowest genetic identity (0.9196) were observed with the GYY and DKL population (Table 5).

The UPGMA dendrogram based on Nei's genetic identity (Fig. 3) exhibited that the 10 natural populations were divided into four groups: population KD, JMS, YMK, GYY, YX and YJ were clustered into group I; population
HZS and SQ were grouped into group II; population KSD and DKL formed group III and group IV, respectively.

The SM values of all samples were calculated by NTSYS-PC 2.10, which ranged from 0.5580 to 0.9227 , with an average of 0.7538 . According to the SM values, the UPGMA dendrogram of all samples was constructed (Fig. 4), in which 196 individuals were obviously clustered into seven categories: 18 individuals from HZS population basically gathered into Group I; all the six individuals from population DKL, seven ones from population HZS and nine ones from population SQ formed Group II; 12 individuals from $\mathrm{KD}$ and 31 individuals from JMS population constituted of Group III and IV, respectively; 12 individuals of GYY, ten ones from YX and 24 individuals from YJ populations were clustered into Group V; nine and 16 individuals from SQ and KSD populations, respectively, formed Group VI; and Group VII was comprised of 18 individuals from YMK population. This showed that except a few individuals were separated out from their own populations and gathered dispersedly with the samples from other populations, most samples from one population can be gathered together. 
1312

Table 4. AMOVA analysis of 10 populations of Fraxinus hupehensis

\begin{tabular}{cccccc}
\hline Source of variation & d.f. & SSD & MSD & Variance component & $\begin{array}{c}\text { Total } \\
\text { variance }\end{array}$ \\
\hline Among populations & 9 & 764.5356 & 84.948 & 3.48 & 16.05 \\
Within populations & 186 & 3385.5868 & 18.202 & 18.20 & 83.95 \\
\hline Note: d.f.: Degrees of freedom; SSD: Sum of squares; MSD: Mean squared deviation ${ }^{2}$ Significance tests after l,000 permutation.
\end{tabular}

Note: d.f.: Degrees of freedom; SSD: Sum of squares; MSD: Mean squared deviation. ${ }^{a}$ Significance tests after 1,000 permutation.

Table 5. The matrix of genetic identity and distances among the 10 populations

\begin{tabular}{|c|c|c|c|c|c|c|c|c|c|c|}
\hline Population & $\mathrm{KD}$ & JMS & DKL & HZS & SQ & KSD & YMK & GYY & YX & YJ \\
\hline $\mathrm{KD}$ & $* * * *$ & 0.9741 & 0.936 & 0.9645 & 0.9702 & 0.9492 & 0.9719 & 0.9644 & 0.967 & 0.9624 \\
\hline JMS & 0.0262 & $* * * *$ & 0.9405 & 0.9616 & 0.9676 & 0.9563 & 0.9727 & 0.9691 & 0.9738 & 0.9682 \\
\hline DKL & 0.0661 & 0.0614 & **** & 0.9383 & 0.9458 & 0.9241 & 0.9326 & 0.9196 & 0.9259 & 0.9288 \\
\hline HZS & 0.0361 & 0.0391 & 0.0637 & $* * * *$ & 0.97 & 0.9575 & 0.9692 & 0.9633 & 0.9697 & 0.9673 \\
\hline SQ & 0.0302 & 0.0329 & 0.0557 & 0.0305 & $* * * *$ & 0.9639 & 0.9663 & 0.9561 & 0.9658 & 0.9633 \\
\hline KSD & 0.0521 & 0.0447 & 0.0789 & 0.0435 & 0.0367 & **** & 0.9584 & 0.9526 & 0.9598 & 0.9554 \\
\hline YMK & 0.0285 & 0.0277 & 0.0698 & 0.0313 & 0.0343 & 0.0425 & $* * * *$ & 0.9648 & 0.9715 & 0.9667 \\
\hline GYY & 0.0363 & 0.0314 & 0.0839 & 0.0374 & 0.0449 & 0.0486 & 0.0358 & **** & 0.9791 & 0.9747 \\
\hline YX & 0.0336 & 0.0266 & 0.077 & 0.0308 & 0.0348 & 0.0411 & 0.0289 & 0.0211 & $* * * *$ & 0.9829 \\
\hline YJ & 0.0384 & 0.0323 & 0.0738 & 0.0333 & 0.0374 & 0.0456 & 0.0338 & 0.0256 & 0.0173 & $* * * *$ \\
\hline
\end{tabular}

Note: Nei's (1972) genetic identity (above diagonal) and genetic distance (below diagonal)

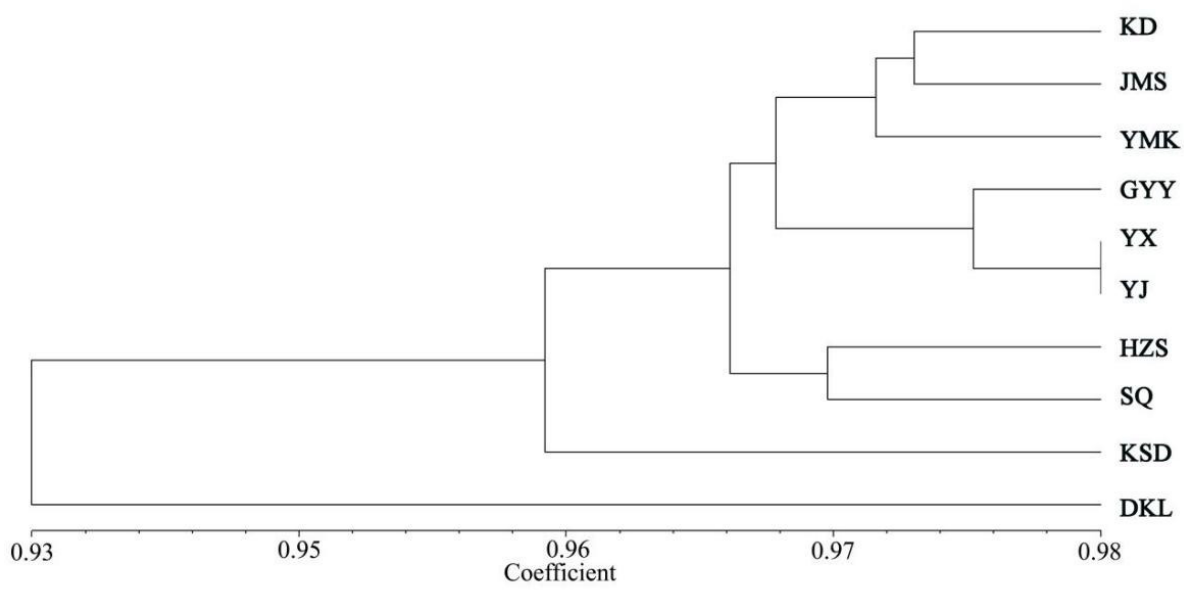

Fig. 3. The UPGMA dendrogram of the 10 populations based on Nei's genetic distance using ISSR markers

\section{Discussion}

Among the 14 primers screened, nine were two-base repeats, of which seven were TC or CT repeats, suggesting that $\mathrm{CT}$ or $\mathrm{TC}$ repeats were more frequently distributed among the genome of the $F$. hupehensis complex. Similar studies were reported on Pyrus (Wang et al., 2010), Nicotiana tabacum (Yang et al., 2005) and so on. Jiang (2006) considered that CT repeat sequences were widespread and abundant in many higher plants.

In recent years, molecular markers have been widely used to study the diversity of endangered plants (Liu et al., 2013; Purayil et al., 2018). The genetic diversity of $F$. hupehensis at the species level (PPL $=100.00 \%, b=0.1833$, $I=0.3041)$ was higher than that at the populations level (PPL=64.06, $h=0.1519, I=0.2434)$. Hamrick and Godt (1997) have shown that the level of genetic diversity and variation of species were positively correlated with the size of its natural distribution region. Species with wide distribution tend to have higher genetic diversity, and vice versa, small populations tend to have lower genetic diversity for the reason of the decrease of genetic variation within population and the increase of mating between individuals (Zhang et al., 2018). Upon this study, the genetic diversity was uneven distribution among ten populations, which may be resulted from the size of the population. For example, the lowest genetic diversity was presented at the smallest Population DKL, and the relatively high level of genetic diversity was taken place at the large scale populations such as HZS and JMS. Compared to that found in previous reports on endangered plants, $F$. hupehensis had a mean level of genetic diversity, which was higher than Ammopiptanthus nanus (Zhao et al., 2016) and Primula malacoides (Crema et al., 2009), and lower than some species such as Sinopodophyllum hexandrum (Xiao et al., 2015), Cupressus chengiana (Hao et al., 2006), and Davidia involucrata (Zhang et al., 2012). 


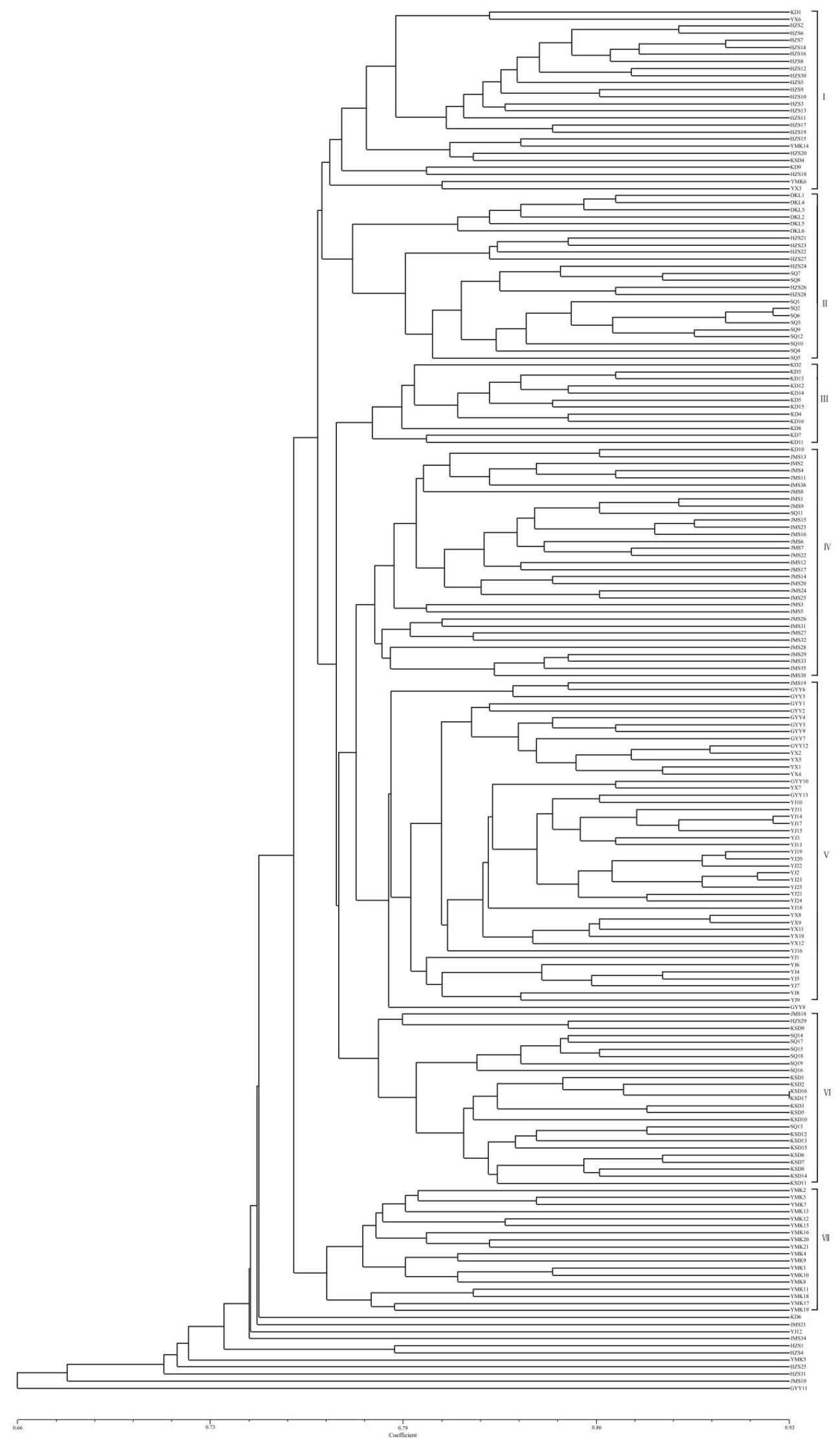

Fig. 4. Dendrogram obtained using the UPGMA clustering method based on SM value among 196 individuals from the 10 populations 
1314

The degree of genetic differentiation of species can be reflected by gene flow (Ellstrand, 2003; Slatkin, 1987). In this work, the $\mathrm{Nm}$ value was $2.4243(>1)$, which reveled resistance to the effects of genetic drift, and thus prevented of the population subdivision (Slatkin, 1987). The degree of genetic differentiation was relatively low (0.1710) as well as the genetic variation mainly occurred within the populations $(83.95 \%)$. The results of dendrogram showed that the populations of YX and YJ were clustered together with shortest genetic distance (0.0173), whereas the geographical distance between the two populations was not the closest; DKL and GYY shared the longest genetic distance (0.0839), however, the geographical distance between the two populations was not the furthest (Fig. 1, Fig. 3), which may prove that there was no correlation between genetic distance and geographical distance among 10 natural populations.

The above results may be attributed to the following reasons: firstly, $F$. hupehensis is a kind of androdioecy species; the cross-pollination would facilitate the gene exchange among individuals within a certain range especially in one population, and consequently increase the degree of genetic diversity within populations to some extent. Meanwhile, the abundant gene flow detected among populations indicated that individuals in different populations might migrate frequently. These are consistent with the results of studies on the genetic variation of Camellia pubipetala (Chai et al., 2014) and Handeliodendron bodinieri ( $\mathrm{Li}$ et al., 2015). Secondly, the species $F$. hupehensis may be continuously distributed in this range until not long ago, and subsequently fragmented into many small chips and even isolated from each other due to the recent changes of natural environment and the effects of modern human activities. Third, the $F$. bupehensis is longevity and its breeding ability is quite low. Field investigation showed that the plants in the wild populations were mainly old adult trees rather than plantlets or young trees. In addition, another study (Liu et al., 2016) suggested that the seeds of $F$. hupehensis were of the long dormancy period and low germination rate. Consequently, the capacities of self-renewal and resisting disturbance of $F$. hupehensis population are poor. This may also explain why as one of the only two species belonged to the section Sciadanthus, $F$. hupehensis remains in Dahongshan Mountains and its neighboring areas in Hubei province of central China, and may extinct in other areas, such as Pakistan, Afghanistan, east and north Africa and the western Himalayas where the other species F. xanthoxyloides (G. Don) DC of the section Sciadanthus is distributed (Wallander, 2008).

\section{Conclusions}

Determination of genetic structure and genetic diversity is of great significance for guiding the protection of in-situ, introduction and cultivation of $F$. hupehensis. Based on the results obtained from this study, on the one hand, the protection strategies should be conducted to protect the representative populations with high genetic diversity and large quantities on site. Especially, the populations GYY, HZS, JMS and YMK should be conserved significantly. On the other hand, the research on the technologies of seed propagation, artificial propagation and seedling breeding should be carried out actively, so as to effectively increase the amount of plants and enrich the germplasm resources of $F$. hupehensis.

\section{Acknowledgements}

This research was supported by the National Natural Science Foundation of China (Grant No. 31200528). This experiment was completed in the Key Laboratory of Horticultural Plant Biology (Ministry of Education), College of Horticulture and Forestry Science, Huazhong Agricultural University. The author sincerely thanked Dr. Xiu-Qun Liu and Dr. Kai-Ge Zhao for their help in analyzing the experimental data, and thanked the members in the laboratory for assistance in the experiment.

\section{Conflict of Interest}

The authors declare that there are no conflicts of interest related to this article.

\section{References}

Anderson JA, Churchill GA, Autrique JE, Sorells ME, Tanksley SD (1993). Optimizing parental selection for genetic-linkage maps. Genome 36(1):181-186

An LH, Zhou H, Sun LS, He ZF, Liu DB, Ren BY (2013). Study on field cuttage propagation technique of Fraxinus hupehensis. Hubei Forestry Science and Technology 2:21-23 (in Chinese with English abstract).

Cao J, Zhou ZC, Tu JF, Cheng SY, Yao JL, Xu F, ... Chen ZX (2019). Genetic diversity and population structure analysis of sand pear (Pyrus pyrifolia) 'Nakai' varieties using SSR and AFLP markers. Notulae Botanicae Horti Agrobotanici Cluj-Napoca 47(3):970-979.

Chai SF, Zhuang XY, Zhou R (2014). Genetic diversity analysis of endangered plant Camellia pubipetala detected by ISSR. Acta Botanica Boreali-Occidentalia Sinica 34(1):93-98 (in Chinese with English abstract).

Crema S, Cristofolini G, Rossi M, Conte L (2009). High genetic diversity detected in the endemic Primula apennina widmer (primulaceae) using ISSR fingerprinting. Plant Systematics and Evolution 280(1/2):29-36.

Ellstrand NC (2003). Current knowledge of gene flow in plants: implications for transgene flow. Philosophical Transactions of the Royal Society ofLondon, Series B-Biological Sciences 358(1434):1163-1170.

Excoffier L, Smouse PE, Quattro JM(1992). Analysis of molecular variance inferred from metric distances among DNA haplotypes: application to human mitochondrial DNA restriction site. Genetics 131(2):479-491.

Hamrick JL, Godt MJW (1997). Allozyme diversity in cultivated crops. CropScience 37(1):26-30.

Hao B, WangL, Mu L, Li Y, Zhang R, Tang M, Bao, W (2006). A study of conservation genetics in Cupressus chengiana, an endangered endemic of China, using ISSR markers. Biochemical Genetics 44(1-2):29-43.

Jiang FX (2006). ISSR study on genetic diversity of lily germplasm resources. $\mathrm{PhD}$ Thesis. Nanjing Forestry University (in Chinese with English 
abstract).

Kimura M, Crow JF (1964). The number of alleles that can be maintained in a finite population. Genetics 49(4):725-738.

Lewontin RC (1972). The apportionment of human diversity. Evolutionary Biology 6:381-398.

Li XP, Guo S, Xiong JF (2015). Genetic diversity of the endangered Handeliodendron bodinieri in Guangxi Province by ISSR and SRAP analysis. Acta Horticulturae Sinica 42(2):386-394 (in Chinese with English abstract).

Liu J, Sun HG, Jiang JM, Shao WH, Luan QF (2013). Genetic diversity of natural populations of Machilus thunbergii, an endangered tree species in eastern china, determined with ISSR analysis. Genetics and Molecular Research 12(3):3689-3697.

Liu L, Liu G, Gong Y, Dai W, Wang Y, Yu Y, Ren Y (2007). Evaluation of genetic purity of $F 1$ hybrid seeds in cabbage with RAPD, ISSR, SRAP, andSSR markers. HortScience 42(3):724727.

Liu YQ, Zhang J, Li G, Wang Q, Xu SY (2016). The research for the germination characteristics of Fraxinus hupehensis seeds. Seed 35(10):2731 (in Chinese with English abstract).

Liu GD, Chen GL, Li W, Li CX (2013). Genetic and phytochemical diversities of Cynomorium songaricum Rupr. in Northwest China indicated by ISSR markers and HPLC-fingerprinting. Biochemical Systematics and Ecology 48:3441.

MarquesJF, Fonseca VF, ShaoZ, Cabral HN, TougardC, BerrebiP(2018). Genetic diversity of Pomatoschistus microps (perciformes: gobiidae) in ecologically differentiated estuarine systems. Folia Zoologica 61(2):106 117.

McDermott JM, McDonald BA (1993). Gene flow in plant pathosystems. Annual Review Phytopathology31(1):353-373.

MingJ, Liao HR (1998). On the present situation of fraxinus hupehensis and its sustainable utilization.Journal of Plant Resources and Environment 7(3):19-22 (in Chinese with English abstract).

Monfared MA, Samsampour D, Sharifi-Sirchi GR, Sadeghi F (2018). Assessment of genetic diversity in Salvadora persica L. based on inter simple sequence repeat (ISSR) genetic marker.Journal of Genetic Engineeringand Biotechnology 16(2):661-667.

Nei M (1973). Analysis of gene diversity in subdivided populations. Proceedings of the National Academy of Sciences of the United States of America 70:3321-3323.

Nishijima R, Ikeda TM, Takumi S (2018). Genetic mapping reveals a dominant awn-inhibiting gene related to differentiation of the variety anathera in the wild diploid wheat Aegilops tauschii. Genetica 146(1):7584.

PengFS (1990). Second batch of national rare and endangered conservative plants in Hubei. Journal of Wuhan Botanical Research 8(4):383-385. (in Chinese with English abstract).

Pomper KW, Crabtree SB, Brown SP, Jones SC, Bonney TM, Layne DR (2003). Assessment of genetic diversity of pawpaw (Asimina triloba) cultivars with intersimple sequence repeat markers. American Society for Horticultural Science 128(4):521-525.
Purayil FT, Kurup SS, Alkhaili MMS, Tawfik NH, Dhaheri SMA, ... Subramaniam S (2018). ISSR-assisted analysis of clonal fidelity supported with SEM and histology using in vitro, propagated plants of Moringa peregrina (Forssk.) Fiori - An endangered desert tree. South African Journal of Botany 114:163-170.

Slatkin M (1987). Gene flow and the geographic structure of natural populations. Science 236(4803):787-792.

Wang CY, Bai JG, Yang YP, Zhao LM, Ji H (1999) Tissue culture plantlet Regeneration of Fraxinus hupehensis. Plant Physiology Journal 1999(04):299-300.

Wallander E (2008). Systematics of Fraxinus (Oleaceae) and evolution of dioecy. Plant Systematics andEvolution 273(1-2):25-49.

Wang CY, Zhao MF, Yao YJ, Wang CJ,Wang CJ, Shu ZM (2001). Study on the cutting technology of Fraxinus hupehensis. Journal of Beijing Forestry University 23(2):18-20 (in Chinese with English abstract).

Wang XC, Jiang SL, Shangguan LF, Cao YF, Qiao YS, Zhang Z, FangJG (2010). Development of Est-derived SSR markers for pear and evaluation of their application in pear genetic diversity analysis. Scientia AgriculturaSinica 43(24):5079-5087.

Xiao M, Li Q, Guo L (2015). RAPD analysis of genetic diversity of an endangered species Sinopodophyllum hexandrum (Royle) Ying from Western Sichuan Province, China. Acta Ecologica Sinica 35(5):14891495.

Yang BC, Xiao BG, Chen XJ, Shi CH (2005). Genetic diversity of fluecured tobacco varieties based on ISSR markers. Hereditas 27(5):753-758.

Ye YM, Wang CY, Shi YL (1999). Preliminary study on cause of seed dormancy of Fraxinus hupehensis. Hubei Agricultural Sciences 4(20):45-47.

Ye J, Xu F, Wang G, Chen Q (2017). Molecular cloning and characterization of an anthocyanidin synthase gene in Prunuspersica (L.) Batsch. Notulae Botanicae Horti Agrobotanici Cluj-Napoca 45(1):2835.

Zhang D, Ren MY, Zhang YD, Guan X (2018). Genetic diversity research on Anisodus tanguticus based on ISSR molecular markers. Chinese Traditional and Herbal Drugs 49(1):219-226.

Zhang J, Ding J, Cheng LL (2014). Preliminary Study on Callus Induction of Fraxinus hupehensis. Chinese Horticulture Abstracts 5:35-36.

Zhang YM, Xu GB, Shen XB (2012). Genetic diversity of Davidia involucrata populations detected by using ISSR markers. Scientia Silvae Sicinae 48(8):63-67.

Zhao P, YongXP, Hu GC (2016). RAPD analysis on the genetic diversity of endangered plant Ammopiptanthusnanus (M.Pop.) Chengf.Journal of Arid Land Resources and Environment 30(3):75-79.

Zietkiewicz E, Rafalski A, Labuda D (1994). Genome fingerprinting by simple sequence repeat (ssr)-anchored polymerase chain reaction amplification. Genomics 20(2):176-183.

Zou XY, Gong JW, Duan L, Jiang X, Zhen Z, Fan SM, ... Lei K (2018). High-density genetic map construction and qt mapping for fiber strength on chr24 across multiple environments in a ccri70 recombinant inbred lines population. Euphytica 214(6):102. 